\title{
Aquatic Invertebrate Fauna of Song Thanh Nature Reserve in Quang Nam Province, Vietnam
}

\author{
Ngo Xuan Nam*, Nguyen Thanh Trung \\ Institute of Ecology and Works Protection, 267 Chua Boc, Dong Da, Hanoi, Vietnam \\ Received 14 August 2017 \\ Revised 8 September 2017; Accepted 12 September 2017
}

\begin{abstract}
The study analyzed the composition of the aquatic invertebrate fauna of Song Thanh Nature Reserve in Quang Nam province of Vietnam. This investigation was realized in March and September 2015. As a result, a total of 166 species belonging to two groups, the zooplankton group has 12 species, 11 genera, 9 families, 3 ordes, 2 classes and the zoobenthos group has 154 species, 120 genera, 59 families, 13 orders, 4 classes. The most richness class is insecta with 141 species, 109 genera, 52 families, 9 orders. Moreover, $\mathrm{pH}$ is the environmental parameter that has more effective than others on zoobenthos group both in dry and rainy seasons; whereas, turbidity and total dissolved solids are two factors that effect more strongly than others on zooplankton group. The number of zooplankton species in dry season is lower than in rainy season and in contrast with zoobenthos species. The species of Crustacea and Bivalvia classes are invisible in the dry season, they only appear the species that belong to insecta and Gastropoda classes.
\end{abstract}

Keywords: Aquatic invertebrate, fauna, Song Thanh, Nature Reserve, Vietnam.

\section{Introduction}

Song Thanh Nature Reserve is not only the first but also the largest area which was established in the West of Quang Nam province. It is conterminous with the Viet - Lao border and belong to Nam Giang and Phuoc Son district.

Song Thanh Nature Reserve shares borders with National Route 14D from Thanh My to Dac Oc border gate (link between Vienam and Lao) on the West East, Kon Tum province on the South (in the peak of Lo So pass), the water

\footnotetext{
*Corresponding author. Tel.: 84-912097556

Email: ngoxuannam@hus.edu.vn

https://doi.org/10.25073/2588-1140/vnunst.4517
}

divide between Thanh River and Cai River on the East, and Lao PDR on the West.

Its forest resources are diverse and abundant. Especially, there were 49 species of plants and 22 species of rare birds, mammals, amphibians, reptiles in Vietnam Red Data Book (2007) and IUCN Red List (2009). It is recorded 301 vertebrate fauna which belong to 89 families, 28 orders; including 53 species of mammal, 183 species of bird, 44 species of reptile, 21 species of amphibian and 25 freshwater fish species. The investigated results showed that there weresome large mammals such as Pantheratigris, Pardus spp., Ursus thibetanus. Song Thanh endemic species include Pygathrix nemaeus, Pygathrix cinerea, Muntiacus vuquangensis, Muntiacus truongsonensis... They are species which have 
high conservation values and biodiversity in Southeast Asia and around the world.

The previous studies have focused on some terrestrial species. Song Thanh Nature Reserve has insufficient data about freshwater species, especially invertebrate groups. Therefore, objectives of this study is to provide a new database of aquatic invertebrate fauna and their relationship with some environmental characterisitics in this area for further research in future.

\section{Materials and Methods}

\subsection{Study area}

A field trip was conducted in 12 sampling sites in the stream system of Song Thanh Nature Reserve, Quang Nam province in 2 seasons: Dry season: March 2015; Rainy season: September 2015.
All of sampling sites are the streams that are denoted by twelve corresponding sites, from 1 to 12 , as below:

\begin{tabular}{|c|c|c|}
\hline Location & Coordinates & $\begin{array}{l}\text { Stream } \\
\text { name }\end{array}$ \\
\hline Site1 & $15^{\circ} 38^{\prime} 54^{\prime \prime} \mathrm{N} ; 107^{\circ} 37^{\prime} 29^{\prime \prime} \mathrm{E}$ & Tra Vinh \\
\hline Site2 & $15^{\circ} 36^{\prime} 06^{\prime \prime} \mathrm{N} ; 107^{\circ} 38^{\prime} 38^{\prime \prime} \mathrm{E}$ & Ta Vat \\
\hline Site3 & $15^{\circ} 35^{\prime} 06^{\prime \prime} \mathrm{N} ; 107^{\circ} 42^{\prime} 20^{\prime \prime} \mathrm{E}$ & $\begin{array}{l}\text { Song } \\
\text { Thanh }\end{array}$ \\
\hline Site4 & $15^{\circ} 35^{\prime} 20^{\prime \prime} \mathrm{N} ; 107^{\circ} 26^{\prime} 55^{\prime \prime} \mathrm{E}$ & $\begin{array}{l}\text { Dak } \\
\text { Dong }\end{array}$ \\
\hline Site5 & $15^{\circ} 34^{\prime} 54^{\prime \prime} \mathrm{N} ; 107^{\circ} 27^{\prime} 27^{\prime \prime} \mathrm{E}$ & La De \\
\hline Site6 & $15^{\circ} 32^{\prime} 50^{\prime \prime} \mathrm{N} ; 107^{\circ} 31^{\prime} 50^{\prime \prime} \mathrm{E}$ & $\begin{array}{l}\text { Dak } \\
\text { Vich }\end{array}$ \\
\hline Site7 & $15^{\circ} 31^{\prime} 31^{\prime \prime} \mathrm{N} ; 107^{\circ} 35^{\prime} 24^{\prime \prime} \mathrm{E}$ & $\begin{array}{l}\text { Dak } \\
\text { Leng }\end{array}$ \\
\hline Site8 & $15^{\circ} 33^{\prime} 00^{\prime \prime} \mathrm{N} ; 107^{\circ} 39^{\prime} 35^{\prime \prime} \mathrm{E}$ & $\begin{array}{l}\mathrm{Pa} \mathrm{La} \\
\mathrm{Ga}\end{array}$ \\
\hline Site9 & $15^{\circ} 20^{\prime} 30^{\prime \prime} \mathrm{N} ; 107^{\circ} 44^{\prime} 20^{\prime \prime} \mathrm{E}$ & $\mathrm{Xa} \mathrm{Ga}$ \\
\hline Site10 & $15^{\circ} 35^{\prime} 29^{\prime \prime} \mathrm{N} ; 107^{\circ} 31^{\prime} 26^{\prime \prime} \mathrm{E}$ & $\begin{array}{l}\text { Cha } \\
\text { Kiep }\end{array}$ \\
\hline Site11 & $15^{\circ} 34^{\prime} 40^{\prime \prime} \mathrm{N} ; 107^{\circ} 31^{\prime} 46^{\prime \prime} \mathrm{E}$ & Cha Kop \\
\hline Site12 & $15^{\circ} 34^{\prime} 51^{\prime \prime} \mathrm{N} ; 107^{\circ} 33^{\prime} 30^{\prime \prime} \mathrm{E}$ & $\begin{array}{l}\text { Dak } \\
\text { Ring }\end{array}$ \\
\hline
\end{tabular}

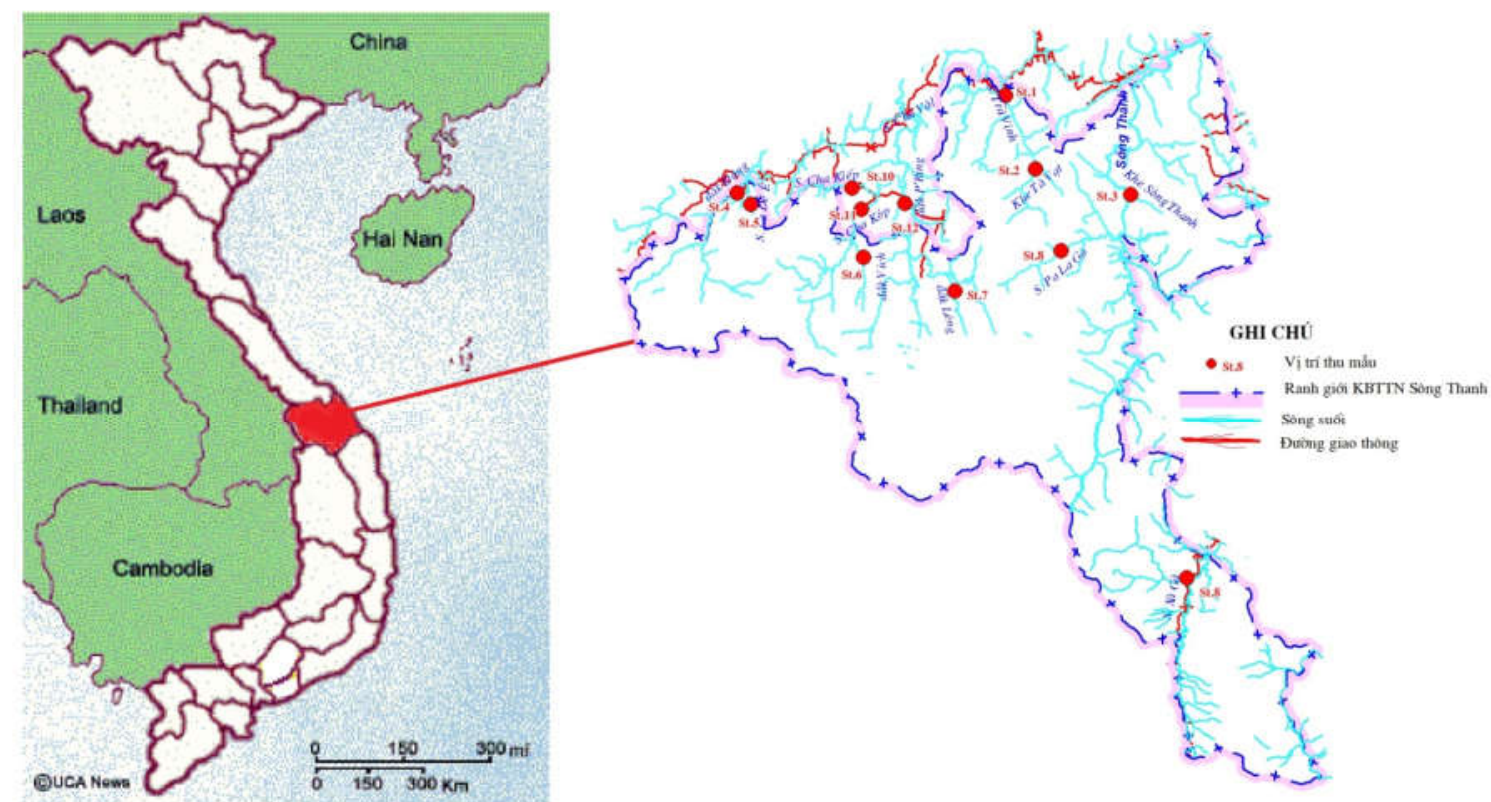

Fig. 1. Sampling sites at major stream at Song Thanh Nature Reserve. 


\subsection{Methods}

Zooplankton species and zoobenthos species was collected by methods illustrated through the researches on freshwater invertebrate of Dang NT (1974) and Nguyen XQ (1995, 2004). [1-3]

Zooplankton sampling method

Taking qualitative sample by zooplankton nets, No. 52 (52 mesh holes $/ \mathrm{cm})$. At each site, swinging the net slowly through the water.

Taking quantitative sample by filtering 10 liters of water over the Plankton net No. 57 (57 mesh holes $/ \mathrm{cm}$ ), retrieved $50 \mathrm{ml}$.

After obtained, the Samples world be held in a vial of capacity of 0.2 liters, with etyket and fixed by $90 \%$ alcohol.

Zoobenthos sampling method

Taking qualitative sample by pond net. When collecting samples, using pond net to scour on grass, small coastal shrubs or floating aquatic trees. For some larvae insects which usually cling to rocks in water, near the shore, using Kick-sampling in the platform or lifting up the stones and rummaging. For insects that lived on the water, catured fastly by the hand net.

Taking quantitative sample by Subber net which has the size $50 \mathrm{~cm} \times 50 \mathrm{~cm}$. Samples obtained by sieving to remove mud, gravel and other substrates.

After obtained, the Samples would be held in a vial of capacity of 0.2 liters, with etyket and fixed by $90 \%$ alcohol.

After the field trip, all samples were shaped, preserved and dissected at the Institute of Ecology and Works protection. Samples were picked from mud and litter, preserved in $90 \%$ alcohol with etyket before dissecting.

Analytical instruments are microscopes, magnifying glasses, petri dishes, microscope slide, cover slip, sharp needles, forceps... Invertebrate were identified to species level or the lowest possible taxonomic levels based on the available references, e.g., Brandt (1974), Cao T.K.T (2002), Hoang Duc Huy (2005),
John et al. (1994), Nguyen XQ et al. (2001), Dang NT et al. (1980), Dang NT (1980, 2002, 2003, 2004), Dang NT và Ho TH $(2001,2002$, 2007, 2012), Dang NT and Do VT (2007), Nguyen Van Vinh (2003), Nguyen Van Vinh and Bae Y.J (2005). [4-20]

Quantitative zooplankton samples were counted by improving Bogorov counting chamber under stereoscopic magnifier, the units: individuals $/ \mathrm{m}^{3}$.

Quantitative zoobenthos samples were counted visually bynaked eye or using magnifying glass, the units: individuals $/ \mathrm{m}^{2}$.

In addition to species samples, 6 physiochemical parameters were measured for each site, including Tempereture $\left({ }^{\circ} \mathrm{C}\right) ; \mathrm{pH}$, Turbidity (NTU); Conductivity $(\mathrm{mS} / \mathrm{cm})$; Dissolved oxygen (DO-mg/l); Total dissolved solids (TDS, mg/l).

\subsection{Data analysis}

The data was stored and managed by Excel program (MS Office ${ }^{\mathrm{TM}}$ v. 2007). Some ecological analyses were performed by using statistical software of PRIMER ${ }^{\mathrm{TM}}$ v.6 with a prior data transformation. The analysis includes DIVERSE (Shannon Weiner index, H'); number of species, $S$; number of individuals or abundance, N; CLUSTER analysis (Bray-Curtis similarity and the cluster mode of group average).

Determining the relationship between the biomes with environmental factors: BEST (Biota and/or Environment matching, BIOENV). BIO-ENV consists of 2 matrices: Similarity of biological data matrix (using Bray-Curtis similarity index) and environmental factors matrix (using the Euclidean distance). Rho correlation coefficient $(\rho)$ is calculated based on two matrices via Spearman correlation range. The results of BIO-ENV would identify and classify a subset of environmental variables corresponding to species composition of the Samples by Rho ( $p$ $=0.01$ ). 


\section{Results}

\subsection{Environmental characteristics of streams}

Study results about environmental characteristics of stream includes altitude; substrate; water width, temperature, $\mathrm{pH}$, turbidity, conductance, dissolved oxygen and total dissolved solids in rainy season and dry season were presented in Table 1.

The bottom substrate of the streams was mainly sand, gravels and boulders; little mud litter and leaf litter. Water width has changed between rainy season and dry season. The average altitude of streams was $452.3 \pm 177,4 \mathrm{~m}$. The average water temperature, the average $\mathrm{pH}$, the average turbidity, the average conductance, the average dissolved oxygen, the average total dissolved solids in dry season were $28.44 \pm 1.39^{\circ} \mathrm{C}, 6.95 \pm 0.44,68.68 \pm 30.91$ (NTU), $0.034 \pm 0.018 \quad(\mathrm{mS} / \mathrm{cm}), \quad 5.58 \pm 0.54 \quad(\mathrm{mg} / \mathrm{l})$, $41.67 \pm 21.67(\mathrm{mg} / \mathrm{l})$ respectively, and in rainy season are $25.1 \pm 0.41^{\circ} \mathrm{C}, \quad 7.08 \pm 0.19$, $140.96 \pm 30.95$ (NTU), $0.023 \pm 0.007(\mathrm{mS} / \mathrm{cm})$, $6.70 \pm 0.56 \quad(\mathrm{mg} / \mathrm{l}), \quad 50.0 \pm 30.15 \quad(\mathrm{mg} / \mathrm{l})$ respectively. Based on the National criteria for surface waters (MONRE, 2011), values of the 3 environmental parameters met the requirement for aquatic fauna reserve.

\subsection{Species diversity}

The results have identified a total number of 166 aquatic invertebrate species in 12 sites of Song Thanh Reserve, of which there were 12 species of zooplankton in 11 genera, 9 families, 3 orders, 2 classes; 154 species of zoobenthos belong to 120 genera, 59 families, 13 orders, 4 classes.

Zooplankton: Some families in Rotatoria phylum have 1 genus and 1 species such as Brachionidae (Branchionus caudatus), Asplanchnidae (Asplanchnopus multiceps), Euchlanidae (Euchlanis dilatata) and Trichicercidae (Trichocerca capucina). Especially, Lecanidae has 1 genus (Lecane) and 2 species (Lecane bulla and Lecane luna).

Some families in this Arthropoda have 1 genus and 1 species such as Bosminidae
(Bosminopsis deitersi) and Diaptomidae (Allodiaptomus mieni). Families has 1 genus and 1 species that is Chydoridae (Chydorus sphaericus sphaericus and Dunhevedia crassa) and Macrothricidae (Macrothrix triserialis and Ilyocryptus haiyi).

Species were found frequently at the study sites were Allodiaptomusmieni (10/12 study sites), Bosminopsisdeitersi (8/12 study sites), Macrothrixtriserialis (7/12 study sites). Trichocercacapucina was only found at La De stream and Dak Ring stream.

Zoobenthos: Ephemeroptera and Odonata have the highest taxonomic levels compared with others. Ephemeroptera had 10 families, 26 genera, 40 species; Odonata with 11 families, 22 genera, 25 species; Followed by Trichoptera with 8 families, 13 genera, 18 species; Coleoptera with 7 families, 15 genera, 16 species; Hemiptera with 7 families, 10 genera, 16 species; Decapoda with 3 families, 4 genera, 5 species; Plecoptera with 1 families, 8 genera, 9 species; Sorbeoconcha with 2 families, 5 genera, 5 species; Megaloptera with 1 family, 1 genus, 2 species. The Lepidoptera, Panpulmonata, Veneroida had only 1 genus, 1 family, 1 species.

Heptagenidae has the highest species with 10 species, 7 genera (Afronurus, Asionurus, peorus, Paegniodes, Rhithrogena, Thalerophyrus, Trichogenia), followed by Perlidae with 9 species, 8 genera (Calineuria, Kamimuria, Kiotina, Neoperla, Periesta, Phanoperla, Phanoperla, Tetropina, Tongoperla) và Gomphidae with 9 species, 7 genera (Gastrogomphus, Heliogomphus, Heliogomphus, Macrogomphus, Megalogomphus, Meliogomphus, Labrogomphus, Leptogomphus, Sinictinogomphus), Baetidae with 8 speices, 5 genera (Acentrella, Baetis, Labiobaetis, Nigrobaetis, Procoeon), Chironomidae with 5 species, 5 genera (Ablabesmyia, Chironomus, Diamesa, Kiefferulus, Thienemannimyia) and Elmidae (Dryomophus, Grouvellinus, Ordobrevia, Stenelmis, Zaitzevia). The remaining orders were found 1 to 4 species. 
Table 1. Environmental data of streams at Song Thanh Nature Reserve

\begin{tabular}{|c|c|c|c|c|c|c|c|c|c|c|c|c|c|c|c|c|}
\hline \multirow[b]{2}{*}{ Location } & \multirow[b]{2}{*}{$\begin{array}{c}\text { Altitude } \\
\text { (m) }\end{array}$} & \multirow[b]{2}{*}{ Substrate } & \multicolumn{7}{|c|}{ Dry Season } & \multicolumn{7}{|c|}{ Rainy Season } \\
\hline & & & $\begin{array}{c}\text { Water } \\
\text { width } \\
\text { (m) }\end{array}$ & $\begin{array}{c}\text { Water } \\
\text { temp. } \\
(\text { oC) }\end{array}$ & pH & $\begin{array}{c}\mathbf{T} \\
(\mathbf{N T U})\end{array}$ & $\begin{array}{c}\mathrm{C} \\
(\mathrm{mS} / \mathrm{cm})\end{array}$ & $\begin{array}{c}\text { DO } \\
(\mathrm{mg} / \mathrm{l})\end{array}$ & $\begin{array}{c}\text { TDS } \\
(\mathrm{mg} / \mathrm{l})\end{array}$ & $\begin{array}{c}\text { Water } \\
\text { width } \\
\text { (m) }\end{array}$ & $\begin{array}{c}\text { Water } \\
\text { temp. } \\
(\text { oC) }\end{array}$ & pH & $\begin{array}{c}\text { T } \\
(\mathbf{N T U})\end{array}$ & $\begin{array}{c}\mathrm{C} \\
(\mathrm{mS} / \mathrm{cm})\end{array}$ & $\begin{array}{c}\text { DO } \\
(\mathrm{mg} / \mathrm{l})\end{array}$ & $\begin{array}{c}\text { TDS } \\
(\mathrm{mg} / \mathrm{l})\end{array}$ \\
\hline Site1 & 292 & $\mathrm{~S}, \mathrm{G}, \mathrm{P}, \mathrm{B}, \mathrm{L}$ & $3-4$ & 29.1 & 6.7 & 108.7 & 0.017 & 4.96 & 40 & $3-5$ & 24.7 & 7.2 & 146.2 & 0.014 & 5.79 & 70 \\
\hline Site2 & 313 & $\mathrm{~S}, \mathrm{G}, \mathrm{B}, \mathrm{L}, \mathrm{M}$ & $4-6$ & 28.8 & 6.7 & 50.3 & 0.013 & 5.69 & 30 & $5-6$ & 24.8 & 7.2 & 125.8 & 0.015 & 6.82 & 10 \\
\hline Site3 & 204 & $\mathrm{~B}, \mathrm{~S}, \mathrm{G}, \mathrm{M}$ & $5-6$ & 28.9 & 6.4 & 73.4 & 0.026 & 5.22 & 20 & $6-8$ & 25 & 7.2 & 124.3 & 0.022 & 7.62 & 10 \\
\hline Site4 & 461 & $\mathrm{~S}, \mathrm{G}, \mathrm{P}, \mathrm{M}$ & $5-7$ & 28.8 & 6.8 & 109.9 & 0.068 & 5.47 & 50 & $8-10$ & 25.2 & 7.1 & 167.6 & 0.03 & 7.55 & 40 \\
\hline Site5 & 583 & $\mathrm{P}, \mathrm{S}, \mathrm{M}, \mathrm{B}$ & $7-12$ & 26 & 6.8 & 23.1 & 0.031 & 5.64 & 30 & $8-13$ & 25.3 & 7.1 & 126.7 & 0.022 & 6.96 & 10 \\
\hline Site6 & 849 & $\mathrm{~S}, \mathrm{G}, \mathrm{B}$ & $4-7$ & 29.4 & 6.8 & 64.2 & 0.059 & 5.23 & 90 & $6-9$ & 25.6 & 7.3 & 122.6 & 0.033 & 6.75 & 60 \\
\hline Site 7 & 657 & $\mathrm{~B}, \mathrm{G}, \mathrm{S}, \mathrm{M}$ & $6-8$ & 28.5 & 6.7 & 95.8 & 0.031 & 6.31 & 50 & $6-9$ & 26.1 & 6.9 & 126.7 & 0.017 & 6.2 & 90 \\
\hline Site8 & 347 & $\mathrm{~S}, \mathrm{G}, \mathrm{B}$ & $4-7$ & 28.7 & 6.8 & 60.4 & 0.025 & 6.63 & 50 & $6-8$ & 25.2 & 6.6 & 131.3 & 0.033 & 6.25 & 60 \\
\hline Site9 & 419 & $\mathrm{~S}, \mathrm{G}, \mathrm{B}$ & $4-6$ & 29.3 & 6.8 & 78.6 & 0.058 & 6.03 & 50 & $5-6$ & 24.9 & 6.9 & 156.4 & 0.018 & 7.23 & 80 \\
\hline Site10 & 490 & $\mathrm{~S}, \mathrm{G}, \mathrm{P}, \mathrm{B}$ & $4-5$ & 25.3 & 7.8 & 14 & 0.023 & 5.77 & 60 & $4-6$ & 24.7 & 7.2 & 225.8 & 0.017 & 6.54 & 30 \\
\hline Site11 & 457 & $\mathrm{~B}, \mathrm{~S}, \mathrm{P}$ & $2-3$ & 30.1 & 7.7 & 93.2 & 0.02 & 4.87 & 10 & $3-5$ & 25 & 7.2 & 124.6 & 0.03 & 6.34 & 90 \\
\hline Site12 & 356 & $\mathrm{G}, \mathrm{P}, \mathrm{M}, \mathrm{B}, \mathrm{L}$ & $7-15$ & 28.4 & 7.5 & 52.6 & 0.036 & 5.23 & 20 & $10-15$ & 24.7 & 7.1 & 113.5 & 0.032 & 6.29 & 50 \\
\hline $\operatorname{Mean} \pm$ SD & $\begin{array}{c}452.3 \\
\pm 177.4\end{array}$ & & & $\begin{array}{l}28.44 \\
\pm 1.39\end{array}$ & $\begin{array}{c}6.95 \\
\pm 0.44\end{array}$ & $\begin{array}{c}68.68 \\
\pm 30.91\end{array}$ & $\begin{array}{c}0.034 \\
\pm 0.018\end{array}$ & $\begin{array}{c}5.58 \\
\pm 0.54\end{array}$ & $\begin{array}{c}41.67 \\
\pm 21.67\end{array}$ & & $\begin{array}{c}25.1 \\
\pm 0.41\end{array}$ & $\begin{array}{c}7.08 \\
\pm 0.19\end{array}$ & $\begin{array}{r}140.96 \\
\pm 30.95\end{array}$ & $\begin{array}{c}\mathbf{0 . 0 2 3} \\
\pm \mathbf{0 . 0 0 7}\end{array}$ & $\begin{array}{c}6.70 \\
\pm 0.56\end{array}$ & $\begin{array}{c}50.0 \\
\pm 30.15\end{array}$ \\
\hline
\end{tabular}

Water width was measured at the sampling points

T (NTU): Turbidity; C (mS/cm): Conductance; DO (mg/l): dissolved oxygen; TDS (mg/l): Total dissolved solids

SD: Standard deviation

Substrate: S: sand, G: gravel, P: Pebble, B:boulder, L: leaf litter, M: mud litter 


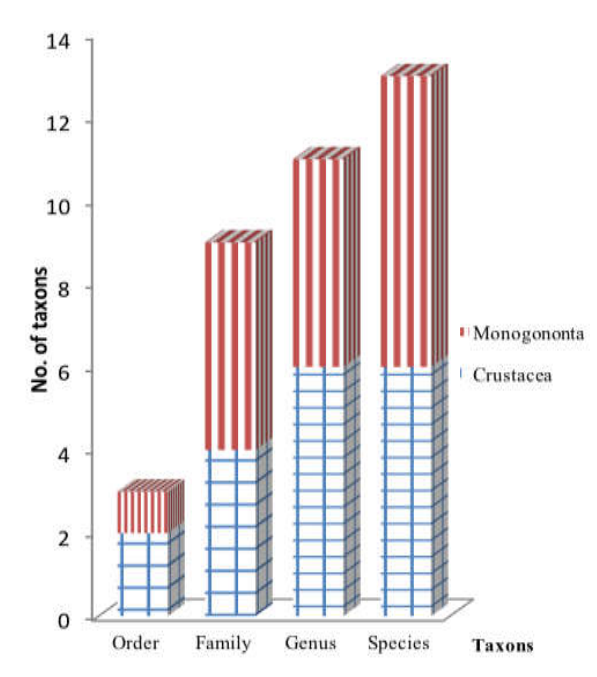

Fig. 2. Taxonomic group of Zooplankton.

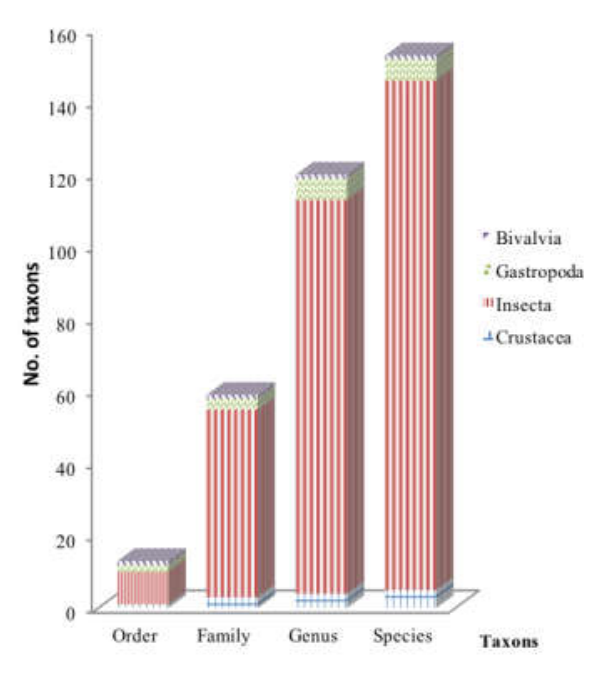

Fig. 3. Taxonomic group of Zoobenthos.
Species occurred regularly in study sites were Paegniodesdao và Hydropsyche bidens (12/12 study sites), Phanoperla sp. and Stenopsyche siamensis (11/12 study sites), Allodiaptomus mieni, Branchycerus sp.1, Lepidostoma sp., Gestroiella limnocoroides (10/12 study sites), Rhoenanthusmagnifucus, Hydropsyche betteni, Corydalus sp. 1, Aeschnophlebia sp. (9/12 study sites), Bosminopsis deitersi, Baetis sp.1, Simulium fenestratum, Labiobaetis sp.2, Ephemera sp.1, Ephemera sp.2, Diplectrona modesta, Eulichas sp. (8/12 study sites).

According to the IUCN Red list, in 2016, there were 15 species at LC level and two species at DD level.

The number and composition structure invertebrate species at Song Thanh Natura Reserve were lower and different with Nature Reserve and Vinh Cuu relics, Dong Nai Province. Ngo Xuan Nam (2014) [21] have identified 303 species belonging to 207 genera, 107 families, 27 orders, 9 classes, 5 phylums; in which, 66 species of zooplankton belongs to 42 genera, 20 families, 6 orders, 2 classes, 237 of zoobenthos included in 165 genera, 87 families, 21 orders, 8 classes. The difference in the number and composition structure of species between two study areas was caused by environmental conditions. In this study, the authors also point out that Insecta had a dominant by 192 species. Besides, the number of zoobenthos in this study was higher than the study of Le Hung Anh et al (2014) [22], in Central Highlands, have identified 60 species of zoobenthos (47 shellfish species, 43 oyster species). The oysters in Central Highlands was more abundant than in the Song Thanh Nature Reserve's.

The number of Insecta species in this study was lower than Sang Woo Jung's (2007) in Sapa (216 species belonging to 139 genera, 61 families and 9 orders), Nguyen et al's. (2001) in Tam Dao National Park (145 species, 127 generaand 63 families), Cao et al.'s (2008) in Bach Ma National Park (143 species, 119 genera and 65 families), and Hoang and Bae's (2006) in Dak Pri stream (268 species, 230 generaand 91 families) [23-25]. Ephemeroptera had the highest species number (40/141 Insecta species, $28,4 \%$ ), this rule was in line with study by Nguyen et al (2001), Cao et al (2008) at the tropical streams $[26,24]$. 
Therefore, the species composition of invertebrate in the Song Thanh Nature Reserve has enormous differences among these classes, and in comparison with other regions in Vietnam. In studies on aquatic invertebrate in the various forms of streams in Vietnam, Insecta dominated by the species composition than the other classes. Aside from, due to fundamental differences between two habitats in the water layer and substrate that makes species composition between the zooplankton and zoobenthos at the same study area become dissimilar.

\subsection{Biodiversity and environment status}

The result of BEST analysis about the correlation between environmental parameters and zoobenthos and zooplankton showed that:

Zooplankton: In the dry season, the combination of environmental parameters, including turbidity, conductance and total dissolved solids, have effected more strongly than others on zooplankton $(\mathrm{Rho}=0.145$, $\mathrm{p}=0.01$ ). In the rainy season, the group of environmental factors, including turbidity and total dissolved solids, have effected more strongly than others $(\mathrm{Rho}=0.357, \mathrm{p}=0.01)$.

Zoobenthos: In the dry season, $\mathrm{pH}$ and total dissolved solids are two invironmental factors that have impact more than others on zoobenthos $(\mathrm{Rho}=0.141, \mathrm{p}=0.01)$. In the rainy season, the group of parameters, including $\mathrm{pH}$, conductance and dissolved oxygen, have effected more than others (Rho $=0.370$, $\mathrm{p}=0.01$ ).

As the result, $\mathrm{pH}$ is environmental parametersthat has more effective than others on zoobenthos group not only in dry season but also in rainy season; whereas, turbidity and total dissolved solids are two factors that effect more strongly than others on zooplankton group.

The result of this investigation is differen with Ngo (2014) at streams of Vinh Cuu Relic and Nature Reserve, Dong Nai province, that is combination factors of temperature and turbidity have impacted on zooplankton in the dry season $(R h o=0.179)$, but in the rainy season, temperature and turbidity have effected on zoobenthos (Rho=0.389), and temperature is the factor has effected more strongly than others in both rainy and dry season $(\mathrm{Rho}=0.281$ and 0.488).

\subsection{The difference of community}

The aquatic invertebrate fauna of the Song Thanh Nature Reserve also has been changed as environmental condition variances between rainy season and dry season. The Bray - Curtis similarity matrix indicates that $26.18 \%$ species is similar between two seasons. The number of zooplankton species in dry season is lower than in rainy season, in contrast to zoobenthos species. In the rainy season, the zooplankton including 11 species, 10 genera, 9 families, 3 orders and the zoobenthos group has 65 species, 57 genera, 36 families, 12 orders. While, in dry season, there were 7 zooplankton species belonging to 6 genera, 6 families, 3 orders and 108 zoobenthos species are in 87 genera, 49 families, 10 orders. In the zooplankton community, Dunhevedia crassa come into view in the rainy season, at 6 streams/12 streams. The above rule accords to Ngo NX (2014) [21].

The species of Crustacea and Bivalvia classes are invisible in the dry season, but only appear the species that belong to Insecta class (107 species) and Gastropoda (1 species). However, in the rainy season, there were 65 species that 5 species are in crustacea class, 53 species belong to Insecta class, 6 species are in Gastropoda class and only 1 species is in Bivalvia class.

For the difference of species combination and individual density, the number of species (S), Shannon Weiner ( $\left.\mathrm{H}^{\prime}\right)$ index is changed in other seasons, between zooplankton and zoobenthos.

The $\mathrm{S}$ and $\mathrm{H}^{\prime}$ index of zoobenthos group is higher in dry season than in rainy season, in constrast with $\mathrm{S}$ and $\mathrm{H}^{\prime}$ index of zooplankton (Table 2.) 


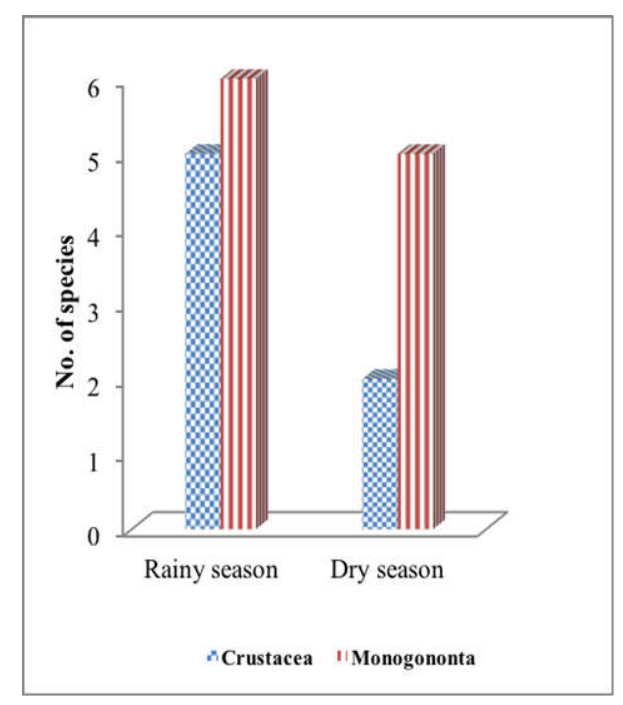

Fig. 4. Number of species in different seasons of Zooplankton.

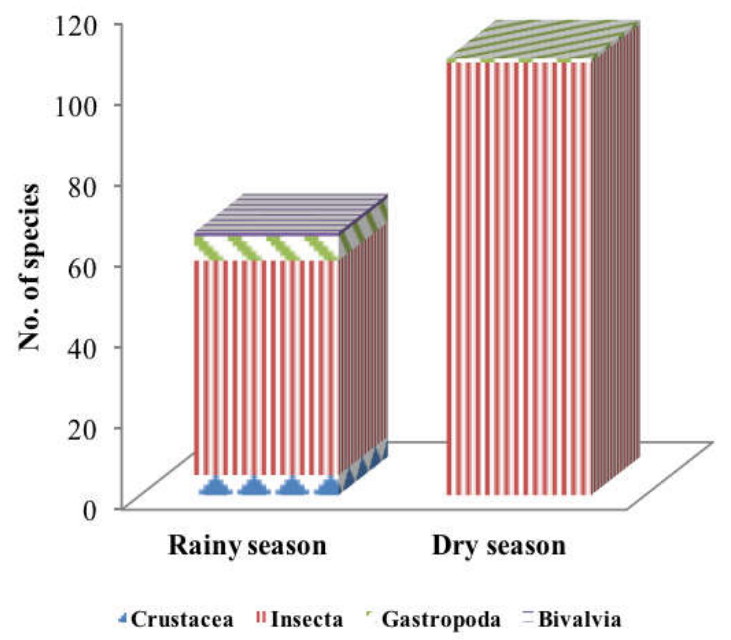

Fig.5. Number of species in different seasons of Zoobenthos.

Fig. 10 Number of species of Zoobenthos and Zooplankton.

As a result of MDS analysis show that the similarity about the species components between site 6 and site 8 (Bray - Curtis index equal 72.44\%), site 9 and site 2 (Bray - Curtis index equal $82.35 \%$ ), because of the difference of environmental conditons of these sites are hightly similar.

Table 2. S and H' index of streams at at Song Thanh Nature Reserve

\begin{tabular}{|c|c|c|c|c|c|c|c|c|}
\hline \multirow{3}{*}{ Location } & \multicolumn{4}{|c|}{ Dry Season } & \multicolumn{4}{|c|}{ Rainy Season } \\
\hline & \multicolumn{2}{|c|}{ Zoobenthos } & \multicolumn{2}{|c|}{ Zooplankton } & \multicolumn{2}{|c|}{ Zoobenthos } & \multicolumn{2}{|c|}{ Zooplankton } \\
\hline & $\mathrm{S}$ & $\mathrm{H}^{\prime}(\operatorname{loge})$ & $\mathrm{S}$ & $\mathrm{H}^{\prime}($ loge $)$ & $\mathrm{S}$ & $\mathrm{H}^{\prime}(\operatorname{loge})$ & $\mathrm{S}$ & $\mathrm{H}^{\prime}($ loge $)$ \\
\hline Site1 & 25 & 2.92 & 3 & 1.03 & 19 & 2.77 & 5 & 1.59 \\
\hline Site2 & 19 & 2.62 & 3 & 1.08 & 16 & 2.62 & 4 & 1.37 \\
\hline Site3 & 17 & 2.55 & 2 & 0.68 & 15 & 2.41 & 5 & 1.52 \\
\hline Site4 & 20 & 2.56 & 4 & 1.37 & 14 & 2.48 & 5 & 1.57 \\
\hline Site5 & 20 & 2.79 & 4 & 1.38 & 13 & 2.43 & 6 & 1.76 \\
\hline Site6 & 20 & 2.73 & 3 & 1.07 & 14 & 2.49 & 4 & 1.29 \\
\hline Site7 & 13 & 2.40 & 3 & 1.10 & 13 & 2.44 & 3 & 1.09 \\
\hline Site8 & 17 & 2.66 & 3 & 1.06 & 16 & 2.54 & 5 & 1.58 \\
\hline Site9 & 19 & 2.67 & 3 & 1.09 & 13 & 2.43 & 4 & 1.29 \\
\hline Site10 & 21 & 2.86 & 4 & 1.38 & 12 & 2.34 & 5 & 1.59 \\
\hline Site11 & 16 & 2.47 & 4 & 1.37 & 12 & 2.34 & 5 & 1.51 \\
\hline Site12 & 21 & 2.725 & 4 & 1.37 & 15 & 2.47 & 7 & 1.92 \\
\hline Mean \pm SD & $\begin{array}{l}19 \\
\pm 3.01\end{array}$ & $\begin{array}{l}2.66 \\
\pm 0.15\end{array}$ & $\begin{array}{l}3.33 \\
\pm 0.65\end{array}$ & $\begin{array}{l}1.16 \\
\pm 0.21\end{array}$ & $\begin{array}{l}14.33 \\
\pm 2.01\end{array}$ & $\begin{array}{l}2.48 \\
\pm 0.12\end{array}$ & $\begin{array}{l}4.83 \\
\pm 1.02\end{array}$ & $\begin{array}{l}1.51 \\
\pm 0.22\end{array}$ \\
\hline
\end{tabular}




\section{Conclusion}

There were total 166 species belonging to two groups, the zooplankton group includes 12 species, 11 genera, 9 families, 3 ordes, 2 classes and the zoobenthos group includes 154 species, 120 genera, 59 families, 13 orders, 4 classes. The most richness class is insecta with 141 species.

$\mathrm{pH}$ is environmental parameters has more effective than others on zoobenthos group both in dry and rainy seasons; whereas, turbidity and total dissolved solids are two factors that effect more st

The Bray - Curtis similarity matrix indicates that $26.18 \%$ species is similar between two seasons. The number of zooplankton species in dry season is lower than in rainy season and in contrast with zoobenthos species. The species of Crustacea and Bivalvia classes are invisible in the dry season.

The $\mathrm{S}$ and $\mathrm{H}^{\prime}$ index of zoobenthos group is higher in dry season than in rainy season, in constrast with $\mathrm{S}$ and $\mathrm{H}^{\prime}$ index of zooplankton.

\section{References}

[1] Dang NT (1974) Outline of hydrobiology. University and vocational schools Publishing House, Hanoi.

[2] Nguyen XQ (1995) Study on invertebrate of wastewater basins in Hanoi area. Thesis for the degree of Ph.D. of biology, Hanoi university of Sciences - Vietnam National University, Hanoi.

[3] Nguyen XQ, Pinder C, Tilling S (2004) Biological monitoring freshwater using large invertebrate. Vietnam National University, Hanoi Publishing House, Hanoi.

[4] Brandt AMF (1974) The non-marine aquatic Mollusca of Thai Lan. Frankfurt.

[5] Cao TKT (2002) Systematics of the Plecoptera (Insecta) in Vietnam. Thesis for the Master's degree, Department of Biology, The Graduate School of Seoul Women's University, Korea.

[6] Hoang Duc Huy (2005) Sytermatics of the Tricoptera (Insecta) of Vietnam. Thesis for Doctor's degree, Department of Biology, The Graduate School of Seoul Women's University.
[7] John CM, Yang L, Tian L (1994) Aquatic insects of China useful for monitiring water quanlity. Hohai University Press, Nanjing.

[8] Nguyen XQ, Pinder C, Tilling S (2001) Identification keys of common freshwater invertebrate in Vietnam. Vietnam National University, Hanoi Publishing House, Hanoi.

[9] Dang NT, Thai TB, Pham VM (1980) Identification of freshwater invertebrate from Northern Vietnam. Science and Engineering Publishing House, Hanoi.

[10] Dang NT (1980) The fauna of freshwater invertebrate from Northern Vietnam. Science and Engineering Publishing House, Hanoi.

[11] Dang NT, Duong DT, Mai DY (2002) Hydobiology of Vietnamese inland freshwater. Science and Engineering Publishing House, Hanoi.

[12] Dang NT, Ho TH, Duong NC, Nguyen XQ (2003) New data of freshwater snails from Vietnam. National Scientific Conference on Ecology and Biological Resources, 2th. Agriculture Publishing House, Hanoi, 731-734.

[13] Dang NT, Ho TH, Duong NC, Nguyen XQ (2004) Viviparidae-Gastropoda from Vietnam. Journal of Biology, 25(4), 1-5.

[14] Dang NT, Ho TH (2001) Fauna of Vietnam, vol. 5. Science and Engineering Publishing House, Hanoi.

[15] Dang NT, Ho TH (2002) Two new species of Potamidae from Vietnam. Journal of Biology, 24(2), 1-8.

[16] Dang NT, Ho TH (2007) Pachychilidae Troschel, 1857 (Gastropoda-Prosobranchia-Cerithioidae) from Vietnam. Journal of Biology, 29(2), 1-8.

[17] Dang NT, Ho TH (2012) Freshwater shrimps, crabs from Vietnam. Natural Sciences and Technology Publishing House, Hanoi.

[18] Dang NT, Do VT (2007) Some new species of Caridina (Crustacea, Decapoda, Atyidae) from Vietnam. Journal of Biology 29(4), 1-12.

[19] Nguyen VV (2003) Systematics of the Ephemeroptera (Insecta) of Vietnam. Thesis for Degree of Doctor science, Department of Biology, The Graduate School of Seoul Women's University.

[20] Nguyen Van Vinh, Bae YJ (2005) Two new records of Heptageniidae (Ephemeroptera, Insecta) in Vietnam. Journal of Science, 21(4), 8085.

[21] Ngo XN (2014) Study on biodiversity of aquatic invertebrates in Vinh Cuu Monument and Nature 
Reserve, Dong Nai province. Thesis for the degree of Ph.D. of biology, Hanoi university of Sciences - Vietnam National University, Hanoi.

[22] Le HA, Nguyen DT, Do VT, Nguyen TC (2014) Diversity of large invertebrate and fish in Tay Nguyen and near threatened species. National Scientific Conference on Ecology and Biological Resources, 5th.

[23] Sang Woo Jung, Nguyen Van Vinh, Quang Huy Nguyen, Bae YJ (2007) Aquatic insect faunas and communities of a mountain stream in Sapa Highland, northern Vietnam. The Japanese Society of Limnology.

[24] Cao TKT, Ham SA, Bae YJ (2008) Aquatic insect fauna of Bach Ma National Park in Thua Thien
Hue province, Vietnam. In: Wang XH (ed) Proceedings of the $3 \mathrm{rd}$ symposium of aquatic entomology in East Asia, The Chinese Society of Aquatic Entomology, Tianjin, China, in press.

[25] Hoang DH, Bae YJ (2006) Aquatic insect diversity in a tropical Vietnam stream in comparison with that in a temperate Korean stream. Limnology 7: 45-55.

[26] Nguyen VV, Hoang DH, Cao TKT, Nguyen XQ, Bae YJ (2001) Altitudinal distribution of aquatic insects from Tam Dao National Park in northern Vietnam. In Bae YJ (ed) The 21st century and aquatic entomology in East Asia. Jeonghaengsa, Seoul, pp 123-133.

\title{
Thành phần loài động vật không xương sống ở nước của khu bảo tồn thiên nhiên Sông Thanh, tỉnh Quảng Nam, Việt Nam
}

\author{
Ngô Xuân Nam, Nguyễn Thành Trung \\ Viện Sinh thái và Bảo vệ công trình, 267 Chùa Bộc, Đống Đa, Hà Nội, Việt Nam
}

Tóm tắt: Kết quả điều tra, khảo sát thu thập vật mẫu vào các tháng 3 và tháng 9 năm 2015 tại 12 địa điểm nghiên cứu tại Khu bảo tồn thiên nhiên Sông Thanh, tỉnh Quảng Nam đã xác định được 166 loài động vật không xương sống ở nước thuộc hai nhóm động vật nổi và động vật đáy. Trong đó, động vật nổi có 12 loài thuộc 11 giống, 9 họ, 3 bộ, 2 lớp và động vật đáy có 154 loài thuộc 120 giống, 59 họ, 13 bộ, 4 lớp. Chiếm ưu thế là các đại diện của lớp côn trùng với 141 loài thuộc 109 giống, 52 họ, 9 bộ. pH là thông số môi trường tương quan chặt hơn với các loài động vật đáy cả trong mùa mưa và mùa khô; Trong khi đó, độ đục và tổng chất rắn hòa tan là hai yếu tố môi trường ảnh hưởng mạnh hơn so với các yếu tố khác đối với động vật nổi. Số lượng các loài động vật nổi vào mùa khô thấp hơn mùa mưa. Vào mùa khô, không thu được mẫu thuộc các lớp Crustacea và Bivalvia, chủ yếu là các đại diện của lớp Insecta và Gastropoda.

Tư khóa: Động vật không xương sống ở nước, động vật, Sông Thanh, Khu bảo tồn thiên nhiên, Việt Nam. 